\title{
From the diasporic to the transnation: Catherine Temma Davidson's The Priest Fainted
}

Jaroslav Kušnír

Jaroslav Kušnír is a Professor of American, Australian and British Literature at the University of Prešov, Slovakia. He is the author of Poetika americkej postmodernej prózy (Poetics of American Postmodern Fiction: Richard Brautigan and Donald Barthelme). Prešov, Slovakia: Impreso, 2001; American Fiction: Modernism-Postmodernism, Popular Culture, and Metafiction. Stuttgart, Germany: Ibidem, 2005; Australian Literature in Contexts. Banská Bystrica, Slovakia: Trian, 2003; and Postmodernism and After: New Sensibility, Media, Pop Culture, and Communication Technologies in Anglophone Literatures. Nitra: ASPA, 2015.

\begin{abstract}
:
This paper analyses the depiction of the main female protagonists of Catherine Temma Davidson's novel The Priest Fainted (1998) in the context of the symbolic formation of the hybrid identity of the main female character and narrator which is close to Bill Ascroft's concept of the transnation. The author of this paper analyses Davidson's depiction of three generations of female protagonists with a Greek cultural background and the way they symbolically represent the transition from a traditional diasporic identity (the narrator's grandmother), through multicultural and transnational identity (her mother) up to the identity close to the concept of the transnation as defined by Bill Aschroft (the narrator herself). At the same time, the formation of such a cultural identity is understood as a symbolic formation of female independence and the rejection of a patriarchal society, religious bigotry and conservative values as represented, in the narrator's and her mother's view, by contemporary Greece.
\end{abstract}

Despite the popularity of Greek culture in the USA, neither Greek-American literature nor the work of Catherine Temma Davidson have become a significant field of study in the $21 \mathrm{st}$ century, unlike other American ethnic writing such as Native-American, Jewish-American, Afro-American, Hispanic-American and Asian-American, which have been much more systematically explored, especially after the 1960s, although in recent years there has been a growing interest in this field led by many Greek and Greek-American academics. Perhaps a genuine exception is represented by the work of Geoffrey Eugenides, whose Middlesex and other works of fiction have been researched intensively and from various perspectives. GreekAmerican literature has often depicted the traditional immigrant experience, the difference 
between the old and the new country/world, the problem of assimilation, and generational conflict. As Gerasimus Katsan argues "Greek American literature has been dominated by the themes of immigration, assimilation and ethnic identity. Greek American authors have often attempted to understand the experiences of the community and their own place within its multivalent, often contradictory, permutations" (Katsan, 2015, p. 101). Vicky Johnson Gatzouras adds that "The use of myths to express an ethnic experience and identity is also present in Greek American literature" (Gatzouras, 2007, p. 117). In her view, "Myths [...] make up a significant subject or theme in contemporary ethnic minority literature of the U.S. [...] In ethnic literature, myths are often employed to shape literary forms as well as contribute to the definition of the artist/writer and his/her ethnic experience" (ibid.). In addition to this, Theodora Tsimpouki proposes "a reading of contemporary Greek-American texts as sites of contestation, where both cultural identities, the American and the pre-American [the identity of descent] are complementary and mutually implicated in each other, and neither part exists in a fully constituted entity" (Tsimpouki, 2005, p. 16). Tsimpouki further argues that these texts "attempt to come to terms with the notion of identity as a cultural construct, which emphasizes the dynamic and changing character of the self, encourages the fluid movement of differences and resists homogenization" (ibid.).

Most of these themes - immigration, assimilation, ethnic identity, the role of myths in contemporary Greek (and Greek-American) culture and in constituting Greek-American cultural identity - appear in Catherine Temma Davidson's novel The Priest Fainted, but she treats these themes, and uses myths, from a different perspective and in a different way, i.e. by the depiction of the female experience, sensibility, psychology and identity which she associates with ethnic identity and the relation between Greece and the USA, i.e. between the country of her (and the main protagonist's) cultural background and the new country she and her main protagonist were born in. She depicts the story of an unnamed young Greek-American woman who is also the narrator of the novel, born in the USA, and who leaves the USA for Greece to both find a job and trace her cultural and ethnic roots there. This story overlaps with the similar story of her mother who can speak Greek, unlike her daughter, and who, living in the USA, made a similar trip to Greece in the 1950s. Thus the story of these women and partly of the narrator's grandmother is not only a story of the relationship between mothers and daughters but also a story on the search for the female, ethnic and cultural identities these women represent.

This fragmented and cyclical narrative also includes the narrator's brief retelling of ancient Greek myths at the beginning of almost each chapter, but although they are used quite 
superficially in the composition of the narrative, they represent the protagonists' connection with traditional Greek culture and a rejection of its patriarchal heritage. In addition, these myths also symbolize archetypal human experience which repeats in both human and the individuals' history. Temma Davidson depicts the formation of a modern Greek-American female identity as not based on binary oppositions between men and women, Greece and the USA, the old and new world, but through sophisticated artistic play, through the use of myths, the imagery of the physical and the spiritual, the religious and the secular. The imagery of the physical and the spiritual, the religious and the secular, past and present are further used in the novel to treat the problematic process of the formation of both the female and ethnic identity of main characters, which is best exemplified by the expression the priest fainted, i.e. the title of the novel, which is further used in many different contexts. "The priest fainted" implies religion, spirituality and a possible tragedy (fainting). But this imagery of the dish is also used in several ironic contexts when the narrator, at the beginning of the novel, reveals it as the name of a traditional Greek family recipe. Theodora Tsimpouki explains the meaning of the name of the recipe, originally 'imam baildi', as an expression referring to "a popular eggplant dish whose genealogy reaches back to the Ottoman period in Greece" (Tsimpouki, 2005, p. 18) and which derives from a combination of the word for an Islamic religious leader and the word for fainting (bayildi in Turkish) and loosely means both to faint and to adore (ibid.).

As Tsimpouki further explains, the legend says the priest fainted because the dish was too succulent (ibid.). The narrator, a young Greek-American woman, says " $[\mathrm{t}]$ he full name of the recipe is Imam Baildi, and, in my family, it means The Priest Fainted. Why did the priest faint? No one knows. Priests in Greece live on high rocks built up to the sky, where they ask for food in baskets to be lifted up to them and where not even the animals they eat are allowed to be feminine. Perhaps the priest was given a bite of bitter and sweet pleasure, and the power of everything behind the dish pushed him off his rock, just for a moment. Perhaps, when he was tumbling through the air, sighing with fear and ecstasy, he saw a glimpse of a new life to come" (Davidson, 1998, pp. 4-5). Despite the fact that the primary meaning of the passage implies the fainting of the priest because of the quality of a traditional Greek dish, in an ironic context it may also represent physicality (eating), secularity and consumerism.

Temma Davidson further develops this imagery of physicality and contextualizes it into other ironic contexts through the depiction of eroticism and possible sexuality associated with the monks in the passage above. Although the forbidden entry of women to some monasteries in Greece seemingly represents a denial of physicality and a turning to spirituality and religion (women representing temptation, possible eroticism and the distraction of monks from praying 
and spirituality), the monks do not represent religion and spirituality as a positive part of Greek heritage. In the grotesque passage above, not religion and religious belief but religious conservativism and a patriarchal society in Greece are rejected; that is the part of the narrator's, the Greek-American daughter's, her mother's and grandmother's cultural heritage which the narrator and her mother are not willing to identify with. It is a tradition which characterizes Greece "as a place of sensuality, irrationality, mystical religiosity, backwardness, and attendant expressions of exoticism" (Tsimpouki, 2005, p. 17).

In addition, the rock and the rock caves the monks are living in not only symbolically represent the monks' separation from the physical world and a symbolic closeness to spirituality (heaven, God) but also a phallic symbol representing male power and patriarchal dominance thus implying a symbolic identification of monks with patriarchal authority and power. The rejection of sexuality representing physicality cannot bring happiness from the young GreekAmerican protagonist's perspective, which is also confirmed by the religious representatives themselves represented by an old but secret religious book written by a monk which was discovered by one of the narrator's friends, a university philosophy professor, during his research in the monastery archives.

Throughout the novel, Temma Davidson further develops the imagery of food and consumerism as juxtaposed with religion and spirituality, mostly referring to traditional Greek culture. What Davidson emphasizes through this narrative strategy and imagery is the shallowness, artificiality, formalism and hypocrisy of religion if practised as a family ritual as a show as well as a manifestation of the masculinity of Greek culture. This manifests itself in many places throughout the novel, and religion and religious belief is connected with the depiction of the eating of traditional Greek meals and mastery of traditional Greek cooking. This imagery is used, on the one hand, as a means of humiliation of other cultures (like Jewish cultures represented by the narrator's Jewish father, who is humiliated by his father-in-law during one such occasion by being offered a peculiar part of the meal, namely an animal eye from the soup, during a dinner he was invited to), or like a consumerist manifestation of religiousness. In this context, Temma Davidson avoids simple binary oppositions and uses the imagery of typical Greek cuisine as imagery representing mother-daughter relations as a counterpart to father-daughter patriarchal relations.

Moreover, the imagery of physicality and sensuality is turned to represent a positive force defining female identity and power in the modern world. This can be seen in the following passage: "Throughout the Levant, on any given day, the aroma of imam rises, the scent of onion and oil, garlic and tomato... Not much goes in and not much gets out, and little has changed in 
four hundred years. Recipes are passed hand to hand, mother to daughter. Girls helping their mothers to prepare simple meals acquire an unspoken knowledge of their palms and fingers. If you come from these villages, you must find your history in your body" (Davidson, 1998, p. 4). On the one hand, this passage seemingly points out the traditional role of women in the history of their patriarchal subjugation (women as mothers and cooks keeping and taking care of the household), on the other hand as both the keepers of the specificity and complexity of cultural tradition and as producers of sensuality now connected with the pleasure of "the aroma" evoking positive sensual feelings which can be symbolically understood as the image of female fragrance as well. The imagery of the meal is thus not used as a symbol of male patriarchal tradition and consumerism but as a symbol of female sensuality, cleverness and independence.

This is further supported by the imagery of the body representing, on the one hand, female cleverness and skill, and on the other hand the sensuality and sexuality connected with it, and with the position of women in modern society. The narrator, the young Greek-American protagonist, does not reject this dish but rather identifies it with her cultural heritage if consumed and enjoyed as a dish representing the specificity of Greek culture, not the spirituality and patriarchal power often present during such occasions according to the narrator. On the other hand, the young protagonist and narrator rejects the typical consumerist character of the American religious holidays, although, at the same time, appreciates her Greek cultural heritage represented by her mother's cooking mastery but especially by her behaviour that evoked a mysterious connection with her Greek heritage during such occasions, as can be seen in the following passage:

In my family, we have always had two Easters: one American and one entirely our own. The first Easter, TV Easter, we shared with all our friends. TV wore pink and white, produced yellow bunnies and lavender eggs... During real Easter, a small window would open and my mother would step into it and come out the other side a different woman, someone with powerful hands and secret knowledge... During Easter I felt I would encounter the core, uncover the mysteries, travel to the origin. (Davidson, 1998, p. 216)

The protagonist's wish to discover her Greek cultural heritage by travelling to and living in Greece, however, becomes a disappointing experience revealing conservatism, religious conservatism, hypocrisy and a patriarchal society she does not want to identify with as a young, modern and independent woman. This patriarchal power further manifests itself in the depiction of various forms of female humiliation and attempts at rape, which are, apparently, seen from 
the narrator's perspective, tolerated in Greek society but rejected by both herself and Isabella, another young Greek-American protagonist and closest friend during the years she lives in Greece. There are characters who humiliate her, such as the gynaecologist who attempts to seduce her during a medical examination, and Leo, both a journalist and her boss at an Athensbased English journal, as well as other unnamed men. As she comments, "I think about all the men who have flashed me since I arrived in Athens. I think about the crowded bus gropers; the hard-on pressed up against your back when the crowd is too tight to move; the old men who pretend to bump into you accidentally in a busy street and, while apologizing, grab your breasts with a painful squeeze" (Davidson, 1998, pp. 201-202).

On the other hand, like her mother in the past, as is gradually revealed, the narrator rejects reconciling herself to the masculine and patriarchal culture and becomes a rebel having free sexual relations with Steve and other men she both chooses and rejects. This symbolizes both her female independence and a rejection of the negative part of her Greek cultural heritage, i.e. the part of Greek culture based on female dependence, the subjugation of women and strong patriarchal relations. Both the manifestation of patriarchal power and its rejection reveal themselves in a sexual scene during which the narrator's lover, Steve, wants her to play the role of a submissive woman, almost a slave, and to call him master: "And then he tells me to call him master. The worlds start to form on my lips... But somewhere between the $t$ and e, the sounds explode into a laugh and the hard $\mathrm{r}$ is never completed... Steve wilts in front of me, and I slide out from under him and sit up" (Davidson, 1998, p. 207). However surprised and initially accepting of this humiliating game during the sexual act, the young Greek-American narrator moves the situation in the other direction and becomes a humiliator herself by mocking Steve, which makes him eventually leave. This symbolically represents both the young GreekAmerican character's transformation and the formation of her female independence, her rejection not only of humiliation but also of contemporary Greek patriarchal society and the values representing contemporary rather than ancient Greek culture, i.e. patriarchy, moral and other corruption, religious bigotry and prejudice.

At the same time, this act also implies a symbolic formation not only of her personal and female but also cultural identity. Realizing the existence of the negative aspects of contemporary Greek culture, like her mother she leaves Greece, but the positive aspects of her Greek cultural heritage she can keep in the USA despite her new homeland, the USA, being criticized for its consumerism and lack of history. She completes a symbolic triad of the formation of her cultural identity represented by three women - the mothers in her family. The initial phase of this formation is represented by her grandmother who had to leave Greece for 
the USA but never learned English and never abandoned her wish and hope to return to the old/mother country, i.e. Greece, which represented a true and ideal homeland for her but, at the same time, a world of non-ancient and rather conservative values the narrator cannot identify with. As the narrator argues about her grandmother who died early in the USA, "We knew she carried the Madonna with her" (Davidson, 1998, p. 258). She further comments on her and imagines that "Perhaps she mourned her mother's house, the herbs in the fields, the sky in all its abundance... Perhaps, instead of wanting her village, she wanted the world. She felt as far from it in New York, behind the metal gates and cement torrents, as she had felt in Retsiani, hemmed in by ta matia tou kosmou, the rules of her ancestors..." (Davidson, 1998, p. 234). This implies that despite the allusion to the grandmother's possible wish to have "the world" become freer and possibly rather cosmopolitan, it might have been only her dreams and imagination that she never changed into reality bur rather remained rooted in her traditional and conservative Greek past by being conservatively religious (carrying the Madonna with her to the USA), or, as can be seen in the following passage, as she became connected with the exotic mysticism defining her past village life in Greece:

More than knowing how to cure the evil eye, my grandmother knew how to cure evil, how to take others' pain away, how to soften suffering. She learned this from her mother, and her mother learned from hers before her. In the mountains, she would have known the name of every herb, what to use to take away fever, to end heartache, to cure madness... Locked into the streets of Queens, where only a few brave trees grow, she still practised her ancient knowledge... (Davidson, 1998, p. 246)

In this sense, then, she can be understood as a typical diasporic character as defined by Safran. In Safran's view, the concept of the diaspora can be applied to the expatriate community living abroad, away from their homeland, and it is a community which, in his view, retains the collective memory, vision or myth about their original homeland; they believe they are not fully accepted by their host society; they consider their original homeland to be their true home to which they want to return; they believe they should contribute to the safety and prosperity of their original homeland and several other features. Referring to the novel, Theodora Tsimpouki argues that "the text is permeated with images of Greece as providing a sense of belonging, and as a site of safety and protection" (Tsimpouki, 2005, p. 25). This sense of belonging, safety and protection is close to both the diasporic imagination and Safran's understanding of the concept of diaspora which is represented mostly by the narrator's grandmother but also by her relatives 
and villagers in Greece, representing her grandmother's true, ideal however distant homeland. As Tsimpouki further observes, "This idealized depiction of Greece is best illustrated by the village communities, which are, according to the author, the heart of the authentic folk culture...the little villages of the plains and the mountains [the grandmother's birthplace] represent the virtues of an original and untarnished folk culture that is untouched by modernity or contact with foreign culture" (Tsimpouki, 2005, p. 22).

In contrast with her grandmother's diasporic character, the narrator's mother and the narrator herself are living in the contemporary USA, but both take similar trips to Greece to trace, recover, and perhaps understand their Greek cultural ancestry and belonging, and they are characters rebelling against the religious conservativism, nationalism and patriarchal way of life they believe contemporary Greece still represents. They complement not only each other's stories and the vision of Greece as a conservative and patriarchal society but also the symbolic formation of their cultural identities which are not homogeneous and diasporic as in Safran's understanding. In the 1950s, when the narrator's mother takes a trip to Greece to see and understand her Greek cultural roots and ancestry, and thus also identity, she rebels against the religious conservativism and patriarchal system in Greece, lives a freer and more independent life, studies at university, and finally marries a Jew in the USA, i.e. a person who is not Greek and who thus is an undesirable husband according to her family. The narrator's mother thus becomes a multicultural and rather transnational character who rejects her diasporic identity and believes the USA is her true home where she can still keep her Greek cultural heritage and roots represented by mystical solidarity between women and by the mastery of cooking traditional Greek dishes which symbolically represent an appreciation of Greek cultural tradition connected with both cooking and holidays.

She confirms this transnational, non-diasporic identity at the end of the novel when she makes another trip to Greece with her daughter, the narrator, to see her best friend from the past, Daphne, who stayed in Greece with her rich husband. The narrator comments on her mother that "My mother left Greece and did not go back for twenty-five years... If she had married the lawyer and stayed with Daphne, she would have been cementing herself into her mother's world - married to an Athenian, not a villager; to a lawyer, not a waiter; but, still, married to a Greek man with Greek expectations. She and Daphne, mirrors of each other, would have been one version of the story - one way it could always turn out. So my mother was not just leaving Daphne, she was abandoning the tracks in the earth laid out for her" (Davidson, 1998, pp. 192-193). And she further continues to comment on her mother's experience and position in the USA in the following way: 
When my mother left Greece, she promised to write... she could write Greek words but not the correct accentuation. She returned to Queens, left quickly for Manhattan. After she married, she traveled even further, to California. Twice a year she cooked Greek dishes, at Christmas and Easter, and drew crowds of every nationality but Greek to sigh and coo over her food... Her cooking was like a sequined gown, brought out only for special occasions... Greek had been her first language; she spoke it for four years before ever learning English. When we grew up, we always asked my mother for definitions, synonyms, new vocabulary... We never realized how much her moods mirrored another place, another country... (ibid., pp. 213-214)

As can be seen from these passages above, they imply both the literal and symbolic formation of the mother's multicultural, transnational and transcultural identity as well as a rejection of her diasporic identity. Her immigration to the USA, her return to Greece to live there for a year in the 1950s, her return back to the USA as well as her final return trip with her daughter to contemporary Greece confirms her rejection of contemporary Greece as a possible homeland and as a symbolic manifestation of her diasporic identity. It also represents a symbolic transition from a diasporic, through transcultural and on to cultural identity, close to Bill Ashcroft's concept of transnation, represented now by the narrator who symbolically complements a formation of this identity. Despite this position, the narrator's mother's first language is Greek, and she regularly keeps the tradition of Greek holidays and cooking which enables her to maintain a closer connection with Greek cultural tradition. However rebellious and independent because of her rejection of marrying a Greek husband, her free lifestyle in Athens during her visit to Greece, and because of the freedom represented by travelling and her education in the USA, she still cannot fully develop her independence and identity as her daughter could later. Her daughter, the narrator, thus represents a symbolic process of both the formation of her transnation identity and an independent, contemporary and free modern woman. During her long visit to Greece to trace her family and cultural roots, she enjoys especially her sexual freedom, "more sexual freedom than the mother" (Tsimpouki, 2005, p. 23) thus undermining the patriarchal and authoritarian model of men-women relations as analysed above. Despite deciding to live in the country with her cousins and relatives for some time, and even partly accepting their traditional way of life, she eventually leaves them and further searches for both her female and cultural identity in a different place, mostly either in the urban environment of Athens or as a tourist on the Greek islands. 
This formation of cultural identity is reminiscent of the process of symbolic maturation and formation of adolescence which Ivona Mišterová comments on in the following way: "Selfperception and commitments in various domains, such as occupational, educational, religious, interpersonal and sexual, thus represent basic components of identity development, which is one of the most important features of adolescence" (Mišterová, 2013, p. 78). The narrator possesses all these features of personal development (study, work, travelling, self-perception, sexual and interpersonal relations, etc.) but the process of growing, maturation and formation of personal identity are rather symbolically turned into the formation of the cultural identity of the narrator. Unlike her mother, she cannot speak Greek very well and she cannot cook the Greek traditional dishes which keep her mother's cultural connection with Greece, and which further implies not only a process of the symbolic separation of the narrator from her Greek cultural roots but also a formation of a specific cultural identity which is close to Bill Ashcroft's concept of the transnation. In Ashcroft's view,

[t]ransnation is the fluid, migrating outside of the state that begins within the nation. This 'outside' is geographical, cultural and conceptual" (Ashcroft, 2010, p. 73). As he also adds, "[...] transnation is a product not only of the nation... but also a product of movement, displacement, relocation. The transnation is both global and local. It not only interpenetrates the state, it interpenetrates the multiplicity of states in their international and global relations... The transnation, by seeing the movement of peoples in globalization as a fundamental feature of spatiality, accentuates the circulation of the local in the global" (Ashcroft, 2010, p. 81).

And Bill Ashcroft further continues,

If we think of the 'transnation' extending beyond the geographical, political, administrative and even imaginative boundaries of the state, both within and beyond the boundaries of the nation, we discover it as a space in which those boundaries are disrupted, in which national and cultural affiliations are superseded, in which binaries of centre and periphery, national self and other are dissolved. (Ashcroft, 2010, p. 73)

At the end of the novel, the narrator says: "By coming to Greece, I had fished into my mother's story, trying to find the beginning. Down in the water, I felt a current pull me, believing its black water. After Easter, I began to swim in the other direction and released a tide of the stories, new versions of what really happened" (Davidson, 1998, p. 233). After meeting 
and living with her relatives for some time and experiencing various aspects of contemporary Greek lifestyle and traditional religious rituals, she says that "I did not realize the strongest feeling I would have by the end of the week would be a desire to get as far away from Greece as quickly as possible" (ibid., p. 216).

The final visit to Greece by the narrator and her mother in the narrative present thus does not become a symbolic return to their cultural roots and a symbolic formation of their diasporic identity but a rejection of this identity as well as the patriarchal and conservative values contemporary Greece represents. At the same, this act of rejection does not mean an acknowledgement of their new American migrant multicultural identity but rather a formation of the subject of the transnation as understood by Bill Ashcroft. It is a cultural identity which is not identified with any of these nations, although it "begins within the nation", which is originally Greece, but which finally becomes a cultural identity that overcomes national boundaries, an identity which is fluid and interpenetrates the multiplicity of states in their international and global relations. Thus the narrator becomes both Greek and American, appreciating various aspects of her Greek roots and Greek cultural identity but, living in the modern world, also accepts her American identity connected with the idea of freedom, independence and consumerism as a natural part of her - what Theodora Tsimpouki would call “bi-culturalism” (Tsimpouki, 2005).

\section{Works Cited:}

Ashcroft, B. 2010.“Transnation.” In: Wilson, J., Sandru, C., Lawson Welsh, S. (eds.). Rerouting the Postcolonial. New Directions for the new millennium. London and New York: Routledge, pp. 72-85.

Davidson, C. 1998. The Priest Fainted. New York: Henry Holt.

Gatzouras Johnson, V. 2007. Family Matters in Greek American Literature. Karlskrona: Blekinge Institute of Technology [dissertation].

Katsan, G. 2015. "Greek America: Literary Representations and Immigrant Narratives in Papazoglou-Maragaris and Petrakis.” In: The Journal of Modern Hellenism, [S.1.], vol. 31, pp. 101-119. Available at: <http://journals.sfu.ca/jmh/index.php/jmh/article/view/24/26>

Mišterová, I. 2013. "Hamleteen: A Search for Identity." In: Mišterová, I., Skopečková, E. (eds.). A Search for Identity. Plzeň: FF ZČU, pp. 64-85.

Safran, W. 1991. "Diasporas in Modern Societies: Myths of Homeland and Return." In: Diaspora: A Journal of Transnational Studies no. 1, pp. 83-99.

Tsimpouki, T. 2005. "Bi-or Mono-culturalism?: Contemporary Literary Representations of Greek-American Identity." In: Pultar, G. (ed.). On the Road to Baghdad or, Travelling Biculturalism. Washington, DC: New Academia Publishing, LIC, pp. 15-26.

Jaroslav K ušnír

Institute of British and American Studies

Faculty of Arts

University of P rešov

17. novembra 1 
08116 P rešov, Slovakia

jaroslav.kusnir@unipo.sk 